\title{
First record of the jewel beetle Anthaxia midas midas (Coleoptera, Buprestidae) in Anatolia (Turkey, Asia)
}

\author{
Primer registro de escarabajos joya Anthaxia midas midas (Coleoptera, Buprestidae) para Anatolia (Turquía, Asia)
}

\author{
HACI HÜSEYIN CEBECI ${ }^{1}$
}

\begin{abstract}
The jewel beetle, Anthaxia midas midas, is reported here for the first time on Acer undulatum. There is no previous evidence of its occurrence in Asia. The present study now adds this subspecies to both the entomofauna of Anatolia region of Turkey and Asia.
\end{abstract}

Key words: Anthaxini, Babadag, distribution, biodiversity.

Resumen: El escarabajo joya, Anthaxia midas midas, es registrado por primera vez sobre Acer undulatum. No hay evidencia previa de su presencia en Asia. Este estudio añade esta subespecie a la entomofauna de Anatolia (Turquía) y Asia.

Palabras clave: Anthaxini, Babadag, distribución, biodiversidad.

\section{Introduction}

Acer undulatum is an endemic species in the Babadag area of Fethiye on the southwestern of Turkey. This species sometimes spreads in single or small groups and sometimes together with cedar trees between 1,400-1,800 masl. Despite the difficulties of climatic conditions and the short vegetation period, it continues its existence in the nature. This endemic plant species is among the threatened species on the red list of the International Union for the Conservation of Nature (Guner 1998).

Species of Anthaxia Eschscholtz, 1829 genus in Turkey are abundant in orchards, conifer and hardwood forests and the studies of Bily (2006), Brandl (1987), Niehuis (1989), Novak (1992), Karaman and Tezcan (1998), Tezcan and Billy (1998), Tozlu (2002), Ulay and Tezcan (1998), Bolu and Özgen (2011), Baiocchi (2015), Özgen (2016), Özgen and Mamay (2017) have made great contributions to the richness of Turkish fauna. Especially, Karaman and Tezcan (1998) evaluated up to 40 species the composition of the Anthaxia fauna of Turkey.

Anthaxia midas midas Kiesenwetter, 1857 is a nominal subspecies of polytypic species, that $A$. midas has three subspecies, $A$. m. midas Kiesenwetter, 1857, A. m. oberthuri Schaefer, 1937 and A. m. spathuligera Obenberger, 1924, and distributes in Mediterranean and sub-Mediterranean countries occurring on hardwood trees including Acer spp., Platanus spp. and Ranunculus spp. (Bily 2006; Sakalian 2003). This subspecies is particularly favorable the hot and humid atmospheric holes under the sunny Mediterranean sky (Herve 1957). Also, San Martin et al. (2000) noted that it is abundant on shrubs such as Prunus espinosa L. and $P$. mahaleb L.

This subspecies distributes in Albania, Bosnia Herzegovina, Bulgaria, Crotia, France, Greece, Italy,
Macedonia, Romania, Serbia and Thrace region of Turkey (Bily 2006). There is no previous evidence of Anthaxia midas midas occurring in Asia; and this study now adds this species to the entomofauna of Asia and Anatolian.

\section{Materials and methods}

A survey was carried out to find the causes of disintegration of wood in Fethiye district of Mugla province of Turkey (36 $31^{\circ}$ '53'N 2910'48'E) between March and September in 2009. Samples infested with this subspecies were picked up and taken to the laboratory in cages for rearing under natural conditions $\left(20-24{ }^{\circ} \mathrm{C}, 60-70 \% \mathrm{RH}\right)$ and six larvae were taken cultures, thus immature insects in the wood tissue could reach the adult stage. They emerged as two females and four males from the samples. All of specimens are found in Lodos Entomological Museum, Turkey (LEMT).

Material examined. Anthaxia midas midas. $2 \uparrow, 4 \hat{\jmath}$. TURKEY. Mugla, Fethiye, Babadag $36^{\circ} 31^{\prime} 53^{\prime \prime} \mathrm{N}$ 29¹0'48’'E. 1620 m. 28-March-2009. Cebeci, H. (LEMT).

\section{Results}

Genus Anthaxia Eschscholtz, 1829

Anthaxia midas midas Kiesenwetter, 1857

It was observed larvae engraving in sapwood and adults on weakened or injured trees due to the negativity in the environment. Adults feed on flowering plants next to $A$. undulatum. Also, the larvae in samples brought to laboratorysustained growth and developed on creating gallery in sapwood. Later, adults formed a D-shaped exit holes on logs (Fig. 1). All adult specimens were identified as Anthaxia midas midas. They are uniformly chestnut-brown in color

\footnotetext{
${ }^{1} \mathrm{Ph}$. D. Istanbul University, Faculty of Forestry, Department of Forest Entomology and Protection, Istanbul, Turkey, hcebeci@istanbul.edu.tr. Corresponding author: Haci Hüseyin Cebeci. Ph. D. Istanbul University, Faculty of Forestry, Department of Forest Entomology and Protection, Istanbul, Turkey.
} 

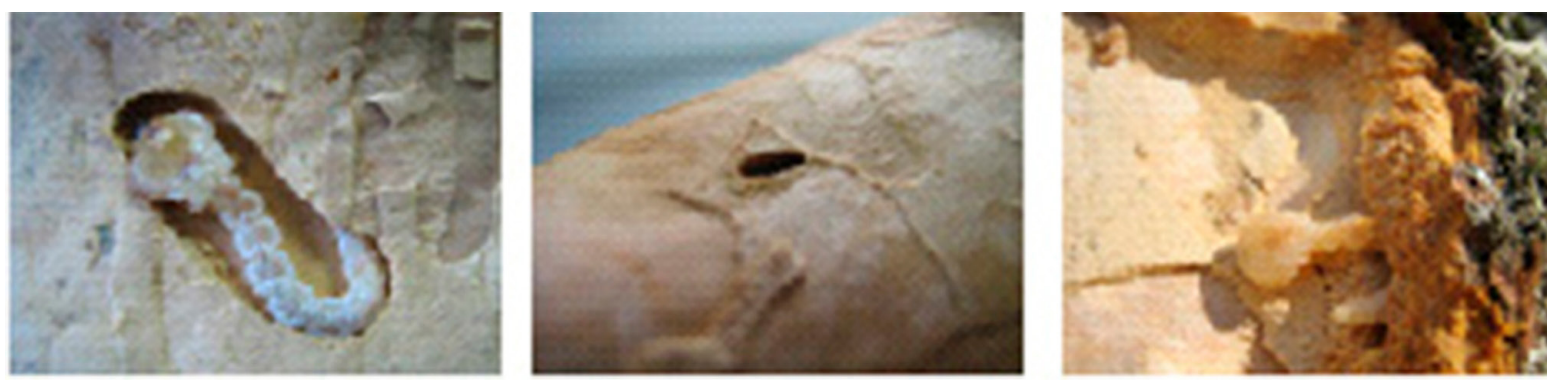

Figure 1. Larvae and exit-hole of Anthaxia midas midas Kiesenwetter, 1857.

and cylindrical and have a typical broad-nosed appearance with a straight short rostrum and compact clubbed antennae. The rostrum is slightly longer than wide and is longer than the head. The scrobes reach the lower edge of the eyes and originate a little before the middle of the rostrum. The eyes are flat, legs and antennae reddish brown in color and antennae relatively short and glabrous. The funicle has six antennomeres, the first being equal in length to the second and third together but wider than all the others; the second to sixth antennomeres are clearly wider than long and very compact. The pronotum is tumid, longer than the rostrum and longer than wide, rounded at sides and covered in flat-bottomed pits (Fig. 2). These pits are contiguous at the lateral margins and the pleuron but not on the pronotal disc. The parallel elytral striae are composed of rows of regular more or less equidistant symmetrical pits. The interstriae, of similar width to the striae, are finely punctate and occasionally strigulate.

The locality collected of the species is characterized by very rocky ambient, snowcapped till may, with sparse arboreal covering, predominantly formed by Cedrus sp. and Pinus sp.

\section{Discussion}

The Babadag mountain is in the list of 100 mountains to be preserved by World Heritage Foundation for endemic plants. Babadag and its coves have rich biodiversity of flora and fauna. Butterfly Valley, like Ölüdeniz, Kidrak and Kabak is one of the coves located at the skirts of Babadag. Therefore,
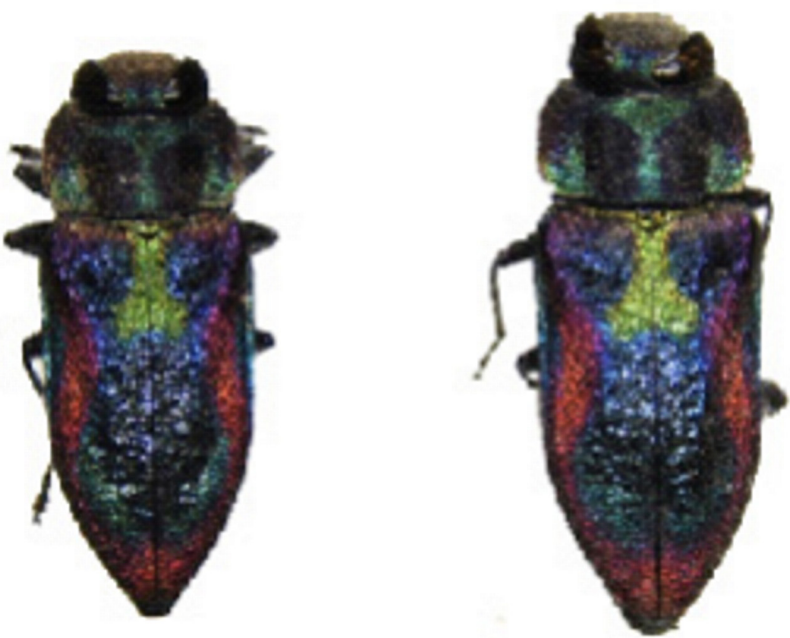

Figure 2. Dorsal views of Anthaxia midas midas Kiesenwetter, 1857.
Babadag and the coves are under legal conservation by Cultural and Natural Heritage Preservation Board.

This species has very sporadic distribution in Babadag which are high-elevation in isolated maple forests of Turkey thus it is subservient to A. undulatum maples. Herve (1957) advised naturalists to be taken protective measures for biocenotic sustainability of species that is endangered in France.

The aim of this report is to share the first impressions, observations and remarks for those interested in nature conservation and biodiversity. Both species and maples should be preserved as certain ecological communities.

\section{Acknowledgements}

I thank Dr. Serdar Tezcan for his valuable comments and identification of species.

\section{Literature cited}

BAIOCCHI, D. 2015. Taxonomic notes on the genus Anthaxia Eschscholtz, 1829 (Coleoptera: Buprestidae: Anthaxiini) 1. Zootaxa 3941 (3): 339-357.

BILY, S. 2006. Buprestoidea. pp. 369-380. In: Löbl, I.; Smetana, A. (Eds.). Catalogue of Palaerctic Coleoptera. Volume 3. Scarabaeoidea, Scirtoidea, Dascilloidea, Buprestoidea, Byrrhoidea. Apollo Books, Stenstrup, Denmark. 690 p.

BRANDL, P. 1987. Anthaxia niehuisi sp. n., eine neue Anthaxia aus der Türkei. Nachrichtenblatt der Bayerischen Entomologen 36 (1): $14-16$.

BOLU, H.; OZGEN, I. 2011. On the Buprestidae (Coleoptera) species of almond orchards in the Southern and Eastern Anatolia in Turkey. Munis Entomology and Zoology 6 (2): 970-975.

GUNER, A. 1998. Acer undulatum. The IUCN Red List of Threatened Species 1998: e.T33003A9746655. http://dx.doi. org/10.2305/IUCN.UK.1998.RLTS.T33003A9746655.en. [Review date: 19 July 2017].

HERVE, P. 1957. La forét de hetres d'aiguines nouvelle localité varoise de l'<Anthaxia midas $>$ Kiesw (El hayedo de Aiguines nueva var localidad de $<$ Anthaxia midas $>$ Kiesw.). Revue Forestiére Française 11: 817-824.

KARAMAN, S.; TEZCAN, S. 1998. Contribution to the study of the genus Anthaxia (subgenus Anthaxia s.str.) Eschscholtz, 1829 (Coleoptera, Buprestidae) of Turkey. Turkish Journal of Entomology 22 (1): 19-35.

NIEHUIS, M. 1989. Anthaxia ursulae sp. n., ein neuer Prachtkäfer aus dem cichorii-Komplex. Nachrichtenblatt der Bayerischen Entomologen 38 (4): 98-105.

NOVAK, G. 1992. Anthaxia (s.str.) herbertschmidi n.sp. Aus der Südtürkei. Zeitschrift der Arbeitsgemeinschaft Österreichischer Entomologen 44 (1-2): 26-28. 
OZGEN, I. 2016. The contributions to Coleoptera (Insecta) fauna in Elazig and Diyarbakir provinces of Turkey. pp. 5906-5909. In: IMSEC, 2016, Congress Book.

OZGEN, I.; MAMAY, M. 2017. Some new faunistic records of Coleoptera from Elazig (Turkey). ICAFOF, 15-17 May, Cappdocia, Turkey, Conference Abstract Book, 1241 p.

SAKALIAN, V. 2003. New data for the distribution of jewel beetles (Coleoptera: Buprestidae) in Turkey. Acta Zoologica Bulgarica 55 (1): 5-10.

SAN MARTIN, A. F.; AGOIZ, J. L.; RECALDE, J. I. 2000. Anthaxia midas (Kiesenwetter, 1857) en Navarra (Coleoptera: Buprestidae). Boletín de la Sociedad Entomológica Aragonesa 27: 78.

TEZCAN, S.; BILY, S. 1998. Contribution to the study of the genus Anthaxia Eschscholtz, 1829 (subgenera Cratomerus Solier, 1833 and Melanthaxia Richter, 1944) (Coleoptera, Buprestidae) of Turkey. Turkish Journal of Entomology 22 (3): 171-186.
TOZLU, G. 2002. Anthaxia lgockii lgockii Obenberger, 1917 (Coleoptera: Buprestidae), new for the Turkish fauna, and new localities for some species of this subgenus. Zoology in the Middle East 25 (1): 99-104.

ULAY, S. M.; TEZCAN, S. 1998. Contribution to the study of the genus Anthaxia Eschscholtz, 1829 (subgenus Haplanthaxia Reitter, 1911) (Coleoptera, Buprestidae) of Turkey. Turkish Journal of Entomology 22 (2): 109-121.

Received: 22-Feb-2017 • Accepted: 13-Jan-2018

Suggested citation:

CEBECI, H. H. 2018. First record of the jewel beetle Anthaxia midas midas (Coleoptera, Buprestidae) in Anatolia (Turkey, Asia). Revista Colombiana de Entomología 44 (1): 135-137. Enero - Junio 2018. 